\title{
VISÃO E PAIXÃO: PROFECIA E OUSADIA
}

Uma Visão impregnada de profecia e uma paixão carregada de ousadia. Assim era Padre Cláudio ...

Quando pensei em uma imagem que expressasse a pessoa de padre Cláudio, veio-me à mente a figura de um tecelão.

A missão do tecelão é aquela de buscar, recolher, juntar, lançar e entrelaçar os fios nas suas diversidades de cores e espessuras.

Essa imagem exprime muito bem minha experiência com padre Claudio.

Uma pessoa de uma visão excepcional, de uma paixão contagiante, por isso era capaz de ousar na missão de unir os fios a serviço do Reino.

No serviço de tecer, corria atrás, convocava, desafiava, inventava, incluía, improvisava.

Um tecelão de sonhos, de projetos, de vidas.

Tecia com os fios do inter.... do intercongregacional, do interreligioso, do intercultural, do interinstitucional e assim por diante...

Ele era, ao mesmo tempo, Tecelão e Fio, porque unia através da sua vida e da sua visão carregada de paixão laços de amizade, de companheirismo, de solidariedade...

Era capaz de entrever, de vislumbrar novos horizontes, novas possibilidades para a missão de uma vida consagrada em saída na Amazônia. Mas uma saída feita em parceria, em aliança com as demais instituições que cuidam da vida.

Visão profética e Paixão ousada são as marcas de uma vida doada sem medida na construção do Reino, para a maior gloria de Deus.

Sou grata a Deus pela oportunidade de ter conhecido padre Claudio. De ter partilhado com ele um pedaço de caminho significativo na minha vida no qual pudemos tecer os sonhos de uma maior colaboração na etapa do noviciado e em outros projetos significativos para nossa congregação.

Obrigada, padre Claudio, pela tua vida doada sem medida, pela tua Visão profética, pela tua ousadia em desafiar e contornar obstáculos e pela tua paixão contagiante. 
Ir. Sônia Matos, ASC. 